\title{
Bundle for the prevention and management of complications of neutropenia in cancer patients
}

\author{
Bundle para prevenção e manejo das complicações de pacientes oncológicos neutropênicos \\ Bundle de la prevención y manejo de complicaciones de pacientes oncológicos neutropénicos
}

$\begin{array}{r}\hline \text { Rosilene Aparecida Costa Amaral' } \\ \text { ORCID: 0000-0001-6825-4689 } \\ \text { Patrícia Peres de Oliveira' } \\ \text { ORCID: 0000-0002-3025-5034 } \\ \text { Deborah Franscielle da Fonseca' } \\ \text { ORCID: 0000-0001-6001-2837 } \\ \text { Thalyta Cristina Mansano Schlosser' } \\ \text { ORCID: 0000-0002-4487-1639 } \\ \text { Juliano Teixeira Moraes' } \\ \text { ORCID: 0000-0002-1109-962X } \\ \text { ORCID: 0000-0001-7378-2240 } \\ \text { Kelli Borges dos Santos"' } \\ \text { ORCID: 0000-0001-8423-9147 } \\ \hline\end{array}$

'Universidade Federal de São João del-Rei. Divinópolis, Minas Gerais, Brazil.

"Universidade Federal de Juiz de Fora. Juiz de Fora, Minas Gerais, Brazil.

How to cite this article: Amaral RAC, Oliveira PP, Fonseca DF, Schlosser TCM, Moraes JT, Silveira EAA, et al. Bundle for the prevention and management of complications of neutropenia in cancer patients. Rev Bras Enferm. 2021;74(2):e20200195 http://doi.org/10.1590/0034-7167-2020-0195

Corresponding author:

Patrícia Peres de Oliveira

E-mail: pperesoliveira@ufsj.edu.br

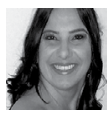

EDITOR IN CHIEF: Antonio José de Almeida Filho ASSOCIATE EDITOR: Alexandre Balsanelli

Submission: $03-25-2020$

Approval: $10-20-2020$

\section{ABSTRACT}

Objectives: to construct and assess bundle content for the prevention and management of complications in neutropenia in cancer patients. Methods: a methodological study developed in four stages: scoping review; bundle construction; material assessment by experts (developed according to Pasquali's psychometry); pilot test in a High Complexity Assistance Unit in Oncology. For content assessment, the Delphi technique was applied in two rounds and those items with Content Validation Coefficient (CVC) $>0.78$ and agreement $>$ $80.0 \%$ were considered valid. Data were analyzed using descriptive and inferential statistics. Results: all bundle requirements reached agreement between judges above $80.0 \%$, in addition to statistically significant levels of assessment. At the end of the Delphi technique, bundle was significantly valid with $C V C=0.92$ and $C V C=0.93$, respectively. Conclusions: bundle content proved to be valid and highly credible.

Descriptors: Neutropenia; Febrile Neutropenia; Drug Therapy, Combination; Nursing Care; Oncology Nursing.

\section{RESUMO}

Objetivos: construir e avaliar o conteúdo de um bundle para a prevenção e manejo das complicações de pacientes oncológicos neutropênicos. Métodos: estudo metodológico, construído em quatro etapas: scoping review; construção do bundle; avaliação do material por especialistas (desenvolvido segundo a psicometria de Pasquali); teste piloto em uma Unidade de Assistência de Alta Complexidade em Oncologia. Para avaliação de conteúdo, aplicou-se a técnica de Delphi em duas rodadas, e considerou-se válidos aqueles itens com Coeficiente de Validação de Conteúdo (CVC) $>0,78$ e consenso $>80,0 \%$. Os dados foram analisados por meio da estatística descritiva e inferencial. Resultados: todos os requisitos do bundle alcançaram concordância entre os juízes superior a $80,0 \%$, além de níveis de avaliação estatisticamente significativos. Ao final da técnica de $D e l p h i$, o bundle se apresentou expressivamente válido com $\mathrm{CVC}=0,92$ e $\mathrm{CVC}=0,93$, respectivamente. Conclusões: o conteúdo do bundle demonstrou ser válido e ter alta credibilidade.

Descritores: Neutropenia; Neutropenia Febril; Quimioterapia Combinada; Cuidados de Enfermagem; Enfermagem Oncológica.

\section{RESUMEN}

Objetivos: construir y evaluar el contenido de un bundle para la prevención y el manejo de complicaciones en pacientes con cáncer neutropénico. Métodos: estudio metodológico, construido en cuatro etapas: revisión del alcance; construcción de bundle; evaluación del material por especialistas (desarrollado según la psicometría de Pasquali); prueba piloto en una Unidad Asistencial de Alta Complejidad en Oncología. Para la evaluación de contenido se aplicó la técnica Delphi en dos rondas, considerándose válidos aquellos ítems con Coeficiente de Validación de Contenido (CVC) $>0,78$ y consenso $>80,0 \%$. Los datos se analizaron mediante estadística descriptiva e inferencial. Resultados: todos los requisitos del bundle alcanzaron acuerdos entre jueces superiores al 80,0\%, además de niveles de evaluación estadísticamente significativos. Al final de la técnica Delphi, el bundle fue significativamente válido con CVC $=0,92$ y CVC $=0,93$, respectivamente. Conclusiones: el contenido del bundle demostró ser válido y tener una alta credibilidad.

Descriptores: Neutropenia; Neutropenia Febril; Quimioterapia Combinada; Atención de Enfermería; Enfermería Oncológica. 


\section{INTRODUCTION}

Currently, there are several forms of treatment for malignant neoplasia, such as antineoplastic chemotherapy (CT), biological therapy, external and intraoperative radiation therapy, radioiodotherapy, brachytherapy, surgeries, in addition to hematopoietic stem cell transplantation $(\mathrm{HSCT})^{(1-2)}$.

CT consists of using chemical substances, alone or in combination, aiming at treating malignant neoplasms acting at the cellular level, interfering in the process of cell growth and division. However, it constitutes a therapy without specificity; therefore, it does not selectively or exclusively destroy tumor cells, causing toxicities and undesirable effects. CT is an indispensable treatment option in cancer treatment ${ }^{(3-4)}$.

Moreover, this therapy causes myelosuppression, favoring febrile neutropenia (FN) and infections. FN occurs when the absolute neutrophil count is less than $1,000 \mathrm{~mm}^{3}$, usually between 7 to 14 days after CT session, called the NADIR period ${ }^{(5)}$.

Thus, fever can be the first and only manifestation of infection, particularly during periods of neutropenia induced by CT. Of the patients receiving $\mathrm{CT}$, more than $80 \%$ will have at least one febrile episode (body temperature is above $38^{\circ} \mathrm{C}$ for more than 60 minutes) during the neutropenia period, and from these, $10 \%$ to $20 \%$ will progress to death, despite the use of broad-spectrum antibiotic therapy ${ }^{(6-7)}$.

However, in some patients, instead of fever, hypothermia, hypotension, or mental confusion may occur, since each individual has an immune response. Thus, the possibility of infection must be considered and treated empirically, if there is any sign of clinical deterioration due to neutropenia, regardless of the temperature measured $^{(7)}$. Generally, recovery takes about one to two weeks and only after this period can a new CT session be submitted ${ }^{(6-7)}$.

Patients who are most likely to develop FN are those with a history of neutropenia over seven days, recent hospitalizations, use of antibiotics, pneumonia, leukemia or lymphoma in patients after 30 days of hematopoietic stem cell transplantation, lower neutrophil count at $100 \mathrm{~mm}^{3}$, bacteremia, Central Venous Catheter (CVC) infection, renal and hepatic failure, other infections $s^{(3,7)}$. FN treatment consists of antibiotic therapy and, normally, patients are hospitalized for hydration and monitoring of signs and symptoms ${ }^{(6)}$.

Individuals with $\mathrm{FN}$ can be classified as low risk, intermediate risk and high risk neutropenic. The risk score is determined using the Multinational Association for Supportive Care of Cancer (MASCC) severity index, which credits points, according to importance, for each variable. The MASCC severity index scores up to a maximum of 26 points (criteria: mild or absent neutropenia intensity - 5 points; absence of hypotension - SBP $\geq 90 \mathrm{mmHg}-5$ points; absence of chronic obstructive disease - 4 points; hematological neoplasia or absence of fungal infection previous - 4 points; absence of dehydration - 3 points; disease intensity: moderate symptoms - 3 points; outpatient fever - 3 points; age $<60$ years - 2 points) and supports patients' classification as low risk ( $\geq 21$ points) or high risk ( $<21$ points) $)^{(5,7)}$.

Due to the inclusion of interpretation of vital signs, including temperature being part of a Nursing Process (NP), it is necessary to update these professionals on the topic. However, it was found in literature that the scarcity of standardization of the prevention and management of complications can mean fragility of care for patients with $\mathrm{FN}^{(6)}$.
In this regard, a bundle implementation for the prevention and management of complications of neutropenia in cancer patients in healthcare practice is paramount. It is noteworthy that bundle is a structured way to improve the care processes for individuals, i.e., a set of evidence-based practices, which when performed collectively and reliably, provide excellent results to patients ${ }^{(8)}$. Research indicates that bundles need to be dynamic and put into practice together with health professionals so that, during their use, it is possible to continuously assess the care provided ${ }^{(9)}$.

In this perspective, Resolution 569 of $2018^{(10)}$ of the Federal Nursing Council (Conselho Federal de Enfermagem) regulates nursing professionals' performance in CT. Among the specific functions of nurses are the development and implementation of therapeutic protocols in the prevention, treatment and minimization of side effects. Thus, bundles have been widely disseminated in hospital institutions, because, when implemented, they are decisive in preventing and reducing complications ${ }^{(9)}$.

Therefore, the relevance of this study is to provide a bundle with the main measures for the prevention and management of complications in neutropenia in cancer patients. Thus, it contributes substantially to the provision of quality care for people with malignancy undergoing $\mathrm{CT}$ treatment.

\section{OBJECTIVES}

To construct and assess bundle content for the prevention and management of complications in neutropenia in cancer patients.

\section{METHODS}

\section{Ethical aspects}

Resolution 466/2012 and 580/2018 of the Brazilian National Health Council (Conselho Nacional de Saúde) guided this study, which was approved by a Research Ethics Committee with Human Beings (COEP) of a federal university in Minas Gerais in April 2017 and by the COEP of the co-participating institution in May 2017. All participants received guidance. After reading and accepting, they signed the Informed Consent Term (ICF), guaranteeing their confidentiality and anonymity throughout the research process.

\section{Design, period, place of study}

This is a methodological research of a bundle content construction and validation for the prevention and management of neutropenia in cancer patients, based on Pasquali's methodological framework ${ }^{(11)}$, with a quantitative approach, guided by the SPIRIT tool. It was developed in four stages: scoping review, bundle construction, assessment of the instrument's content by judges/experts, from May to October 2019, and pilot test in a High Complexity Assistance Unit in Oncology (UNACON) held from November to December 2019.

\section{Inclusion and exclusion criteria; study participants}

Bundle assessment, in order to reach the number of judges recommended by Pasquali ${ }^{(11)}$, i.e., from six to 20 experts, it was decided to invite a larger number, considering that some might not respond or refuse the invitation. 
The selection of judges for validation studies was based on a series of criteria that differ according to the objectives of each research. Time of clinical experience, degree, research experience and publications on the topic addressed were taken into account.

An active search by specialists for advanced research was carried out on the Curriculum Lattes platform of the Brazilian National Council for Scientific and Technological Development (CNPq - Conselho Nacional de Desenvolvimento Científico e Tecnológico) (http://lattes.cnpq.br/) by subject in order to identify health professionals in Brazil able to act as judges of the instrument ${ }^{(12)}$. For this, the simple search form was used, in the field "search for", in the category "subject", using the terms "oncology" and/ or "chemotherapy". Thus, $388 \mathrm{PhD}$ professionals were identified.

To screen the possible judges, the Fehring model ${ }^{(13)}$ was adapted and used, since it measures a maximum score of 14 points; however, for this selection a minimum score of five points was given for having: master's and PhD degrees in nursing or related fields (mandatory criteria); dissertation addressing cancer care (2 points); thesis with subject in oncology ( 2 points); certificate or title of specialist in oncology nursing (1 point); research (es) in oncology in the last five years (3 points); authorship of at least two articles in the last three years in the oncology field ( 3 points); experience in CT and oncology of at least three years (3 points) ${ }^{(13)}$.

After the search, a total of 60 eligible judges were reached. They received an invitation letter by e-mail, with a period of up to 20 days to return the instrument, in addition to the ICF with the necessary instructions to be able to analyze and assess. The instrument to be filled out for the assessment was built on Google Docs, with initial information for the characterization of the participant and the items of the instrument. Each item had a space where the judges could provide suggestions for change and improvement ${ }^{(14)}$.

The Delphi technique was performed. In this way, the specialists answered, through rounds, an evaluative questionnaire. Of the 60 possible judges first selected, 16 agreed to participate in bundle assessment, corresponding to the first round (Delphi I ${ }^{(8,15)}$, when there were suggestions for changes in the instrument for improvement. The changes considered pertinent and, after adjustments, the feedback of the responses was sent together with the bundle, configuring the second round (Delphi II), a stage in which there was the participation of 14 judges (it stands out that these 14 judges participated in the two rounds), with loss of two due to the non-return of the instrument within the established period.

In the fourth stage (pilot test), 12 nurses participated and 30 neutropenic patients of intermediate risk and high risk of FN were assessed. Nurses working in the oncology outpatient department of CT were included. Nurses who were on vacation, on sick leave for health treatment, on maternity leave or on leave for professional training were excluded ${ }^{(16)}$.

The selection of patients was carried out for convenience at an oncology outpatient clinic of CT on the days of collection, meeting the following inclusion criteria: a score of 15 on the Glasgow scale and being under CT treatment for hematological malignancy. This last criterion was based on the result of a study that inferred that hematological cancer patients had more $\mathrm{FN}^{(5,7)}$. The Glasgow scale was applied to ensure that patients had an adequate level of temporal, personal and spatial orientation, as noted in the item "verbal response" on the scale, as well as an adequate motor response
- another item on the scale - in order to comply with some of the guidelines provided for neutropenia control. It is noteworthy that these items, added to the ocular opening, consistently indicate the degree of integration of the central nervous system. Exclusion criteria were established: presenting some solid neoplasm associated with hematology, in order to homogenize the sample.

The sample was designed based on the records of patients registered at a CT outpatient clinic, considering a $95 \%$ confidence level and 5\% sampling error, which resulted in 250 service users. Bearing in mind that it is a pilot study and, for that, a percentage of approximately $10 \%$ is suggested ${ }^{(17)}$.

\section{Study protocol}

Initially, the results derived from the literature review were used, in order to identify the scientific evidence on nursing care for neutropenia in cancer patients through scoping review ${ }^{(18)}$ (according to the PRISMA-SCR recommendations ${ }^{(19)}$ and the method proposed by the Joanna Briggs Institute, Reviewers Manual 2017(20), based on national and international scientific evidence (Chart 1)).

The scoping review protocol ${ }^{(18)}$ was registered in the Open Science Framework (https://osf.io/axwm7), Participants, Concept and Context (PCC) strategy ${ }^{(18-19)}$ was used to construct the research question : $\mathrm{P}$ (participants) - Neutropenic cancer patient, C (concept) - FN after CT and C (context) - Health services that care for cancer patients after CT in FN. Thus, the research questions were: which nursing care are relevant, in the context after $C T$, in relation to FN prevention? Which nursing practices are important in the management of FN complications?

The search strategy was adapted according to the specificities of each database and the analogous combination of descriptors was kept: (Antineoplastic Agents OR Drug Therapy OR Chemotherapy, Adjuvant OR Induction Chemotherapy OR Consolidation Chemotherapy OR Maintenance Chemotherapy OR Medication Therapy Management OR Antineoplastic Combined Chemotherapy Protocols) AND (Chemotherapy-Induced Febrile Neutropenia OR Febrile Neutropenia) AND (Nursing OR Oncologic Nursing).

Articles published with full texts, in Brazilian Portuguese, Spanish and/or English, with no time limit, that addressed nursing care for neutropenia in cancer patients were included. Articles that did not include the guiding questions, editorials, experience reports, scientific communication, reviews, letters, theoretical essays, single case studies were excluded, as well as reviews that only addressed the prevention and management of FN-related complications of cancer patients performed by physicians, dentists, and pharmacists.

The search was carried out from October 2018 to June 2019, in the National Library of Medicine and National Institutes of Health (PUBMED), Cumulative Index to Nursing and Allied Health Literature (CINAHL), Web of Science, SCOPUS, Latin American \& Caribbean Literature in Health Sciences (LILACS) and Cochrane library databases. The articles were selected by two independent reviewers in order to confirm the relevance of the review questions and, if so, to extract the data of interest. All doubts or inconsistencies were resolved by agreement among the authors. For the stage of separation, synthetization and report of the essential information discovered in each study, a structured instrument was used to collect this data, which allowed extent synthesis, interpretation, and analysis, nature and distribution of the studies incorporated in the review ${ }^{(18)}$. 
Chart 1 - References used as a basis for bundle construction, Minas Gerais, Brazil, 2020

\begin{tabular}{|c|}
\hline References \\
\hline $\begin{array}{l}\text { Best JT, Frith K, Anderson F, Rapp CG, Rioux L, Ciccarello C. Implementation } \\
\text { of an evidence-based order set to impact initial antibiotic time intervals in } \\
\text { adult febrile neutropenia. Oncol Nurs Forum. } 2011 ; 38(6): 661-8^{(21)} \text {. }\end{array}$ \\
\hline $\begin{array}{l}\text { Chang LL, Schneider SM, Chiang SC, Horng CF. Implementing an } \\
\text { evidence-based risk assessment tool to predict chemotherapy- } \\
\text { induced neutropenia in women with breast cancer. Cancer Nurs. } \\
\text { 2013;36(3):198-205 }\end{array}$ \\
\hline $\begin{array}{l}\text { Conley SB. Central Line-Associated Bloodstream Infection Prevention: } \\
\text { Standardizing Practice Focused on Evidence-Based Guidelines. Clin J } \\
\text { Oncol Nurs. 2016;20(1):23-6(23). }\end{array}$ \\
\hline $\begin{array}{l}\text { Considine J, Livingston P, Bucknall T, Botti M. A review of the role } \\
\text { of emergency nurses in management of chemotherapy-related } \\
\text { complications. J Clin Nurs. 2009;18(18):2649-55 }\end{array}$ \\
\hline $\begin{array}{l}\text { DeMille D, Deming P, Lupinacci P, Jacobs LA. The effect of the } \\
\text { neutropenic diet in the outpatient setting: a pilot study. Oncol Nurs } \\
\text { Forum. 2006;33(2):337-43(25). }\end{array}$ \\
\hline $\begin{array}{l}\text { Donohue R. Development and implementation of a risk assessment } \\
\text { tool for chemotherapy-induced neutropenia. Oncol Nurs Forum. } \\
\text { 2006;33(2):347-52(26). }\end{array}$ \\
\hline $\begin{array}{l}\text { Duffy EA, Rodgers CC, Shever LL, Hockenberry MJ. Implementing a } \\
\text { Daily Maintenance Care Bundle to Prevent Central Line-Associated } \\
\text { Bloodstream Infections in Pediatric Oncology Patients. J Pediatr Oncol } \\
\text { Nurs.2015;32(6):394-400 }(27) \text {. }\end{array}$ \\
\hline
\end{tabular}

Flores IQ, Ershler W. Managing neutropenia in older patients with cancer receiving chemotherapy in a community setting. Clin J Oncol Nurs. 2010;14(1):81-6(28).

Griffiths P, Richardson A, Blackwell R. Outcomes sensitive to nursing service quality in ambulatory cancer chemotherapy: systematic scoping review. Eur J Oncol Nurs. 2012;16(3):238-46 (29).

Hawley EL, Loney M, Wiece M. Development of tools and processes to improve treatment times in patients with febrile neutropenia. Clinical Journal of Oncology Nursing. 2011;15(5): e53-e57(30).

Kearney N, Friese C. Clinical practice guidelines for the use of colonystimulating factors in cancer treatment: Implications for oncology nurses. Eur J Oncol Nurs. 2008;12(1):14-25(31).

Leonard K. A European survey relating to cancer therapy and neutropenic infections: nurse and patient viewpoints. Eur J Oncol Nurs. 2012;16(4):380-6(32).

Mattison G, Bilney M, Haji-Michael P, Cooksley T. A nurse-led protocol improves the time to first dose intravenous antibiotics in septic patients post chemotherapy. Support Care Cancer. 2016;24(12):5001-05(33).

Miller K. Using a computer-based risk assessment tool to identify risk for chemotherapy-induced febrile neutropenia. Clin J Oncol Nurs. 2010;14(1):87-91(34).

Montoya L. Managing hematologic toxicities in the oncology patient. J Infus Nurs. 2007;30(3):168-72(35).

Moore K, Crom D. Hematopoietic support with moderately myelosuppressive chemotherapy regimens: a nursing perspective. Clin J Oncol Nurs. 2006;10(3):383-8 ${ }^{(36)}$.

Moore K, Fortner B. Utility of routine nurse assessment of the risk of chemotherapy-induced febrile neutropenia. Can Oncol Nurs J. 2010 Spring;20(2):75-9(37).

Nirenberg A, Mulhearn L, Lin S, Larson E. Emergency department waiting times for patients with cancer with febrile neutropenia: a pilot study. Oncol Nurs Forum. 2004 13;31(4):711-5(38).

Nirenberg A, Reame NK, Cato KD, Larson EL. Oncology nurses' use of National Comprehensive Cancer Network clinical practice guidelines for chemotherapy-induced and febrile neutropenia. Oncol Nurs Forum. 2010;37(6):765-73(39).
Chart 1 (concluded)

\section{References}

O'Brien C, Dempsey O, Kennedy MJ. Febrile neutropenia risk assessment tool: improving clinical outcomes for oncology patients. Eur J Oncol Nurs. 2014;18(2):167-74(40).

Olsen JP, Baldwin S, Houts AC. The Patient Care Monitor-Neutropenia Index: development, reliability, and validity of a measure for chemotherapyinduced neutropenia. Oncol Nurs Forum. 2011;38(3):360-7(41).

Shelton BK, Stanik-Hutt J, Kane J, Jones RJ. Implementing the surviving sepsis campaign in an ambulatory clinic for patients with hematologic malignancies. Clin J Oncol Nurs. 2016; 20(3):281-8(42).

Smith LH, Besser SG. Dietary restrictions for patients with neutropenia: a survey of institutional practices. Oncol Nurs Forum. 2000;27(3):515-20(43).

Tarakcioglu CGH, Korkmaz F. Nurses' knowledge and care practices for infection prevention in neutropenic patients. Contemp Nurse. 2017;53(2):143-55(6).

White N, Maxwell C, Michelson J, Bedell C. Protocols for managing chemotherapy-induced neutropenia in clinical oncology practices. Cancer Nurs. 2005;28(1):62-9(44).

Ying FLM, Ping MCY, Tong M, Yan EYP, Yee TLS, Ting LY, et al. A cohort study on protocol-based nurse-led out-patient management of postchemotherapy low-risk febrile neutropenia. Support Care Cancer. 2018;26(9):3039-45(7).

Zhou Y, Cui Y, Wang H, Wang F, Lu C, Shen Y. Developing a tool for nurses to assess risk of infection in pediatric oncology patients in China: a modified Delphi study. J Biomed Res. 2016 Sep;30(5):386-92 ${ }^{(45)}$.

The critical assessment of sources of evidence is optional in the scope of the scoping review ${ }^{(19-20)}$. In this study, we opted to perform it in order to meet one of the objectives of the review, which was to be a reference for constructing the bundle. In accordance with evidence-based practice, the conduct described in the bundle was analyzed and classified according to Melnyk and FineoutOverholt's proposal ${ }^{(46)}$, which systematizes the levels of evidence in: level I - arising from systematic review or meta-analysis of trials randomized, controlled clinical trials or clinical guidelines based on systematic reviews of randomized controlled clinical trials; level II - from at least one well-designed randomized controlled clinical trial; level III - from well-designed clinical trials without randomization; level IV - derived from a cohort and case-control study, both well-designed; level V - proceeding from a systematic review of descriptive and qualitative studies; level VI - arising from a single descriptive or qualitative study; level VII - from the opinion of authorities and/or expert committee reports ${ }^{(46)}$.

The bundle construction stage, initially had 37 items, distributed in five modules: 1) concerning risk factors; 2) concerning prevention; 3) concerning management; 4) concerning specific management for pediatrics; 5) concerning the nursing team. Each of these modules was analyzed according to the assessment criteria instituted by Pasquali(11): behavior, objectivity, simplicity, clarity, relevance, precision, variety, modality, typicality, credibility, breadth, and balance. It should be noted that there was a chart clarifying each of these 12 criteria, and they were assessed using a Likert-type scale, being:"1 - inadequate (I)","2 - partially adequate $(P A)$ "; $" 3$ - adequate $(A)$ ".

The fourth stage referred to a pilot test performed at a UNACON for 30 consecutive days in November and December 2019. Initially, its implementation in the chemotherapy outpatient clinic and in the oncology inpatient unit was carried out to train nursing professionals to use it. 
Two workshops were held in a private room in the study setting, with an average duration of 40 minutes, with nurses and the researcher in charge of the research, with a view to training for the use of the prevention and management of complications bundles for neutropenia in cancer patients. Validation of available material and human resources was included, in addition to viable care according to cost, ease of implementation and adherence to these measures. It should be noted that the workshops were organized, according to participants' preference and availability.

\section{Data analysis}

The assessments performed by judges on the bundle were inserted in Microsoft Excel 14.0 ${ }^{\circledR}$. After analyzed, the scores attributed to each item were verified. The relevance of all items was obtained by applying Content Validity Coefficient (CVC) ${ }^{(11)}$. The item with more than $80 \%$ agreement between the judges (assessed as adequate) and a CVC $>0.78$ was considered valid ${ }^{(11)}$.

Furthermore, descriptive and inferential analysis (binomial test) was performed. Agreement among judges and CVC scores acquired in the Delphi rounds. For this, $p$ value $\leq 0.05$ was chosen as a parameter for statistical significance.

\section{RESULTS}

When constructing the bundle, it became evident that, in the initial format, one item was joined to another previously listed. The changes made consisted essentially of simplicity (aims only at an idea for a given item and allows for proper understanding), clarity (content has simple and unambiguous expressions), precision (each item of the instrument occupies a defined and distinct position from the others) and in the modality (phrases with extreme expressions were avoided), resulting in increased agreement. The finished bundle had 36 items (Chart 2).

Chart 2 - Bundle for the prevention and management of complications of neutropenia in cancer patients, Minas Gerais, Brazil, 2020

\begin{tabular}{|l|l|c|}
\hline \multicolumn{3}{|l|}{ BUNDLE FOR THE PREVENTION AND MANAGEMENT OF } \\
COMPLICATIONS OF NEUTROPENIA IN CANCER PATIENTS \\
\hline Conduct & \multicolumn{1}{|l|}{ Actions/Measures } & $\begin{array}{c}\text { Level of } \\
\text { evidence }\end{array}$ \\
\hline & $\begin{array}{l}\text { a) To determine patients'lack of } \\
\text { knowledge and information about } \\
\text { the disease, treatment and care to } \\
\text { be used. }\end{array}$ & ॥ \\
\hline & $\begin{array}{l}\text { b) To assess the risk factors for FN such } \\
\text { as advanced age, previous FN, radiation } \\
\text { therapy and/or previous CT, associated } \\
\text { comorbidities, previous hospitalizations, } \\
\text { aggressive or metastatic cancer, } \\
\text { catheter manipulation, weakened } \\
\text { immune system, low levels of albumin, } \\
\text { hematological diseases (leukemias, } \\
\text { lymphomas or other bone marrow } \\
\text { diseases). }\end{array}$ & ॥ \\
\hline factor & $\begin{array}{l}\text { c) To assess issues such as psychosocial } \\
\text { well-being, lifestyle, organic functions } \\
\text { (kidney, liver, heart function); recovery } \\
\text { of spinal cord activity, people } \\
\text { recently submitted to HSCT, SIRS and } \\
\text { hemodynamic instability. }\end{array}$ & ॥ \\
\hline
\end{tabular}

Chart 2

BUNDLE FOR THE PREVENTION AND MANAGEMENT OF COMPLICATIONS OF NEUTROPENIA IN CANCER PATIENTS

\begin{tabular}{|c|c|c|}
\hline Conduct & Actions/Measures & $\begin{array}{l}\text { Level of } \\
\text { evidence }\end{array}$ \\
\hline \multirow{3}{*}{$\begin{array}{l}\text { Concerning risk } \\
\text { factor }\end{array}$} & $\begin{array}{l}\text { d) To pay attention to the handling } \\
\text { of catheters properly, especially } \\
\text { semi-implantable catheters (more } \\
\text { susceptible to infection than fully } \\
\text { implantable catheters. }\end{array}$ & VI \\
\hline & $\begin{array}{l}\text { e) To pay attention to hand and } \\
\text { equipment hygiene, which can } \\
\text { be channels of transmission of } \\
\text { pathogens to cancer patients. }\end{array}$ & II \\
\hline & $\begin{array}{l}\text { f) To guide patients to avoid closed } \\
\text { places with clusters of people and } \\
\text { individuals with contagious diseases. }\end{array}$ & VI \\
\hline \multirow{7}{*}{$\begin{array}{l}\text { Concerning } \\
\text { prevention }\end{array}$} & $\begin{array}{l}\text { a) To observe the use of G-CSFs, } \\
\text { especially in the first cycle of CT, since } \\
\text { it decreases the incidence, duration } \\
\text { and severity of hospitalizations for FN } \\
\text { or other neutropenic complications, } \\
\text { in addition to minimizing reductions } \\
\text { in CT doses and possible delays. } \\
\text { Recommended for patients over } 65 \\
\text { years of age; spinal cord infiltration; } \\
\text { open wounds; active infections or } \\
\text { other serious comorbidities; received } \\
\text { extensive previous treatment or CT } \\
\text { and combined radiation therapy, } \\
\text { and received a CT regimen with a } \\
\text { documented rate of FN greater than } \\
20 \% \text {. }\end{array}$ & II \\
\hline & $\begin{array}{l}\text { b) To pay attention to the } \\
\text { proper administration of G-CSFs } \\
\text { subcutaneously. The drug should } \\
\text { be started } 24 \text { hours after CT and } \\
\text { repeated every } 24 \text { hours. When } \\
\text { G-CSF is used in patients treated } \\
\text { with weekly CT regimens, it should } \\
\text { be stopped } 24 \text { hours before next } \\
\text { treatment, once G-CSF has been } \\
\text { used in } 1 \text { cycle, it must be used in all } \\
\text { subsequent cycles of the same form. }\end{array}$ & VI \\
\hline & $\begin{array}{l}\text { c) To continuously assess the risk } \\
\text { factors for post-chemotherapy FN. }\end{array}$ & IV \\
\hline & $\begin{array}{l}\text { d) To guide patients and family } \\
\text { members about the importance of } \\
\text { hand hygiene and disinfection of } \\
\text { materials. }\end{array}$ & II \\
\hline & $\begin{array}{l}\text { e) To carry out an outpatient nursing } \\
\text { consultation (offer patients a tangible } \\
\text { education, to reinforce post-CT care } \\
\text { to prevent FN, risk of sepsis and } \\
\text { clarify patients' doubts). }\end{array}$ & IV \\
\hline & $\begin{array}{l}\text { f) To periodically schedule laboratory } \\
\text { tests for patients after } C T \text { to assess the } \\
\text { immune system, explaining the need } \\
\text { for it to continue with } C T \text { treatment. }\end{array}$ & IV \\
\hline & $\begin{array}{l}\text { g) To advise patients to use } \\
\text { Telenursing whenever necessary } \\
\text { (use technology to provide guidance } \\
\text { to patients, especially those from } \\
\text { distant regions/use appropriate } \\
\text { communication to avoid generating } \\
\text { errors). This feature allows } \\
\text { professional and patient proximity, } \\
\text { provides integration, protection and } \\
\text { security. }\end{array}$ & IV \\
\hline
\end{tabular}


Chart 2

BUNDLE FOR THE PREVENTION AND MANAGEMENT OF
COMPLICATIONS OF NEUTROPENIA IN CANCER PATIENTS

\begin{tabular}{|c|c|c|}
\hline Conduct & Actions/Measures & $\begin{array}{l}\text { Level of } \\
\text { evidence }\end{array}$ \\
\hline $\begin{array}{l}\text { Concerning } \\
\text { prevention }\end{array}$ & $\begin{array}{l}\text { h) To observe the occurrence and start } \\
\text { immediate treatment for vomiting, } \\
\text { mucositis, diarrhea, which are } \\
\text { predisposing factors to the onset of } \\
\text { infection, which may contribute to FN. }\end{array}$ & IV \\
\hline \multirow{6}{*}{$\begin{array}{l}\text { Concerning } \\
\text { management }\end{array}$} & $\begin{array}{l}\text { a) To request the start of antibiotic } \\
\text { therapy within } 1 \text { hour to guarantee } \\
\text { positive effects in the treatment, } \\
\text { avoid possible organizational } \\
\text { problems, such as delays in filling out } \\
\text { the prescription, problems with the } \\
\text { system with a specific form, delays in } \\
\text { transferring the emergency service } \\
\text { to the inpatient unit, problems with } \\
\text { the pharmacy process, or delay in } \\
\text { medication administration. }\end{array}$ & VII \\
\hline & $\begin{array}{l}\text { b) To perform exam collection, if } \\
\text { neutrophils are less than } 500 \mathrm{~mm}^{3} \text {, } \\
\text { temperature higher than } 38.0^{\circ} \mathrm{C} \\
\text { and patients received } \mathrm{CT} \text { in the last } \\
14 \text { days. Collect blood culture and } \\
\text { urine samples (according to the } \\
\text { institutional protocol) and send them } \\
\text { to the laboratory on an urgent basis } \\
\text { and start the antibiotic. To perform } \\
\text { exams for kidney, liver, urine culture } \\
\text { (IN) colproculture (IN) imaging exams } \\
\text { radiology, ultrasound, tomography. } \\
\text { Perform culture of other sites, such as } \\
\text { catheters. }\end{array}$ & VI \\
\hline & $\begin{array}{l}\text { c) To assess the antibiotic used, in } \\
\text { cases of low risk (oral antibiotic } \\
\text { therapy). In high-risk cases, patients } \\
\text { must be hospitalized and use } \\
\text { intravenous antibiotics. }\end{array}$ & IV \\
\hline & $\begin{array}{l}\text { d) To perform early sepsis screening, } \\
\text { source assessment, timely } \\
\text { administration of appropriate } \\
\text { antibiotics and management of } \\
\text { infusion. Fever should be recognized } \\
\text { as an emergency and antibiotics } \\
\text { should be used promptly to prevent } \\
\text { sepsis, septic shock and death. }\end{array}$ & V \\
\hline & $\begin{array}{l}\text { e) To pay attention to the } \\
\text { recombinant human G-CSF that } \\
\text { stimulates the proliferation of bone } \\
\text { marrow progenitor cells and their } \\
\text { differentiation into functional blood } \\
\text { cells, which helps in the recovery of } \\
\text { patients with neutropenia. G-CSF } \\
\text { can be administered to patients } \\
\text { who are experiencing an episode } \\
\text { of FN ("secondary prophylaxis"). } \\
\text { Recommendations include starting } \\
\text { treatment with CSFs } 24 \text { hours after CT } \\
\text { administration. }\end{array}$ & VI \\
\hline & $\begin{array}{l}\text { f) To monitor nutritional status and } \\
\text { advise patients not to eat raw foods if } \\
\text { their neutrophil is less than } 500 \mathrm{~mm}^{3} \\
\text { (neutropenic patients should avoid } \\
\text { raw foods due to the presence of } \\
\text { bacteria in food, should avoid raw } \\
\text { dairy products, herbs, honey, fruits } \\
\text { and fresh vegetables, cold meats and } \\
\text { cheeses and water from wells (so } \\
\text { include well-cooked foods in meals). }\end{array}$ & VI \\
\hline
\end{tabular}

Chart 2

BUNDLE FOR THE PREVENTION AND MANAGEMENT OF
COMPLICATIONS OF NEUTROPENIA IN CANCER PATIENTS

\begin{tabular}{|l|l|l|}
\hline Conduct & Actions/Measures & $\begin{array}{c}\text { Level of } \\
\text { evidence }\end{array}$ \\
\hline & $\begin{array}{l}\text { g) To assess signs and symptoms, } \\
\text { grade of FN patients is in (grade } \\
\text { zero }-2,000 \mathrm{~mm}^{3} \text { or higher, grade } \\
1-1,500 \text { to } 1,999 \mathrm{~mm}^{3}, \text { grade } 2 \text { - } \\
1,000 \text { to } 1,499 \mathrm{~mm}^{3}, \text { grade } 3-500 \\
\text { to } 999 \mathrm{~mm}^{3} \text { and grade } 4-\text { less than } \\
500 \mathrm{~mm}^{3} \text { ) and monitor vital signs for }\end{array}$ & \\
\hline
\end{tabular}

$500 \mathrm{~mm}^{3}$ ) and monitor vital signs for

4/4 hours or whenever necessary

according to patients' clinical

picture using devices exclusively

for patients with FN or performing

Concerning

disinfection of the devices to avoid

management cross contamination.

h) To perform hand hygiene, prepare the necessary materials for the procedure, rub the catheter hub with antiseptics (alcoholic chlorhexidine $0.5 \%$ or alcohol $70 \%$ ). Access catheters with sterile devices only. To perform the dressing change of the fully implantable catheter every 7 days in case of transparent film and replace the dressings in cases of dirt, damp or loose.

a) To pay attention to the dosage of antibiotics, since most are fractionated. They must be equipped with a graduated chamber and/ or use of the infusion pump, which allows the infusion of medicines at the appropriate dosage and time.

b) To assess the child's psychosocial issues and family support (the Concerning specific presence of parents helps during management for treatment). To provide a pleasant, pediatrics creative, quiet place for recovery.

c) To establish dialogue with children, using a language that is easy to understand and adapted to their age. Knowing how to listen to questions carefully.

d) To carry out the selection of appropriate equipment for children, such as equipment and extenders, micropores, splints.

a) To promote the continuing professional qualification to prevent and recognize possible complications related to FN such as sepsis, pneumonia, cellulite.

b) To emphasize the importance of hand hygiene before the preparation and administration of medications,

Concerning the recommendations to the nursing team punctures, catheter handling.

c) To educate patients about the disease, FN and post-CT care.

d) To instruct patients and family members to take care at home, when checking the temperature, signs and symptoms that should be reported to a health professional

(such as: fever, chills, bleeding, persistent pain even with the use of prescription drugs). 
Chart 2 (concluded)

\begin{tabular}{|l|l|c|}
\hline \multicolumn{3}{|l|}{ BUNDLE FOR THE PREVENTION AND MANAGEMENT OF } \\
COMPLICATIONS OF NEUTROPENIA IN CANCER PATIENTS \\
\hline \multirow{5}{*}{ Conduct } & Actions/Measures & $\begin{array}{c}\text { Level of } \\
\text { evidence }\end{array}$ \\
\hline & $\begin{array}{l}\text { e) To asses patients before CT } \\
\text { treatment (investigation and nursing } \\
\text { diagnoses), in order to elaborate } \\
\text { relevant interventions (perform } \\
\text { nursing consultation periodically). }\end{array}$ & IV \\
\cline { 2 - 3 } & $\begin{array}{l}\text { f) To encourage nurses to discuss the } \\
\text { need for hematopoietic support with } \\
\text { other members of the health team. }\end{array}$ & V \\
\hline & $\begin{array}{l}\text { g) To assess the risk of FN in order } \\
\text { to design supportive care plans, } \\
\text { considering the myelosuppressive } \\
\text { potential of the treatment regimen. }\end{array}$ & IV \\
\cline { 2 - 3 } $\begin{array}{l}\text { Concerning the } \\
\text { recommendations } \\
\text { to the nursing team }\end{array}$ & $\begin{array}{l}\text { h) To use an evidence-based } \\
\text { approach to nursing care. }\end{array}$ & IV \\
\hline & $\begin{array}{l}\text { i) To document the results and } \\
\text { response to treatment before the } \\
\text { next CT cycle to be administered. }\end{array}$ & IV \\
\hline & $\begin{array}{l}\text { j) To monitor possible complications } \\
\text { of patients, especially elderly people, } \\
\text { children and individuals most likely } \\
\text { to become myelosuppressed. }\end{array}$ & IV \\
\hline
\end{tabular}

Note: HSCT - hematopoietic stem cell transplantation; SIRS - systemic inflammatory response syndrome; FN - febrile neutropenia. CT - antineoplastic chemotherapy; G-CSFs - granulocyte colony stimulating factors; IN - if necessary

PhD professionals with practical experience in oncology (mean $=23.10$ and standard deviation $=9.87$ in Delphi l; mean $=22.39$ and standard deviation $=10.34$ in Delphi II) participated in teaching. The minimum age of specialists was 30 years old and maximum of 62 years old ( mean $=46.18$ and standard deviation $=10.79$ in Delphi l; mean $=46.0$ and standard deviation $=11.44$ in Delphi II), whose mean length of training was 24.10 years and standard deviation $=7.63$ in Delphi l; mean $=23.28$ and standard deviation $=8.72$ in Delphi II. Most currently work in oncology and in teaching, $56.3 \%$ and $50 \%$, respectively (Table 1 ). They practiced in northeastern, southeastern, and southern Brazil.

Table 1 - Characterization of judges participating in Delphi I and II phases, Minas Gerais, Brazil, 2020, $(n=16$ and $n=14)$

\begin{tabular}{|c|c|c|}
\hline Characterization of judges & $\begin{array}{c}\text { Delphi I } \\
(n=16) n(\%)\end{array}$ & $\begin{array}{c}\text { Delphi II } \\
(n=14) n(\%)\end{array}$ \\
\hline \multicolumn{3}{|l|}{ Sex } \\
\hline Female & $14(87.5)$ & $12(85.7)$ \\
\hline Male & $2(12.5)$ & $2(14.3)$ \\
\hline \multicolumn{3}{|l|}{ Age } \\
\hline From 30 to 40 years & $5(31.3)$ & $5(35.7)$ \\
\hline 41 to 50 years & $5(31.3)$ & $5(35.7)$ \\
\hline 51 to 60 years & $4(25.0)$ & $3(21.4)$ \\
\hline Over 60 years & $2(12.4)$ & $1(7.2)$ \\
\hline \multicolumn{3}{|l|}{ Time passed since graduation in nursing } \\
\hline More than 10 years & $14(87.5)$ & $12(85.7)$ \\
\hline Less than 10 years & $2(12.5)$ & $2(14.3)$ \\
\hline \multicolumn{3}{|l|}{ Currently operating área } \\
\hline $\begin{array}{l}\text { Teaching and assistance and/or } \\
\text { management in oncology }\end{array}$ & $9(56.3)$ & $7(50.0)$ \\
\hline Teaching & $4(25.0)$ & $4(28.5)$ \\
\hline Teaching and management in oncology & $2(12.5)$ & $2(14.3)$ \\
\hline Assistance and/or management in oncology & $1(6.2)$ & $1(7.2)$ \\
\hline
\end{tabular}

Table 2 describes the final agreement among the judges regarding the analyzed items of bundle content for the prevention and management of complications of neutropenia in cancer patients, who obtained agreement ("adequate"), according to Pasquali's assessment criteria.

According to what was shown in Table 2, it was observed that none of the items were below what is recommended in the actions/measures for the prevention and management of complications of neutropenia in cancer patients so that such bundle would be considered valid in Delphi I. it was possible to reach an agreement index for all analyzed items regarding the bundle content, in which relevance/pertinence and balance were the best assessed (CVC $=0.96$ and CVC $=0.94$, respectively). Concerning the general estimate, the instrument had CVC $=0.92$ in this stage.

It should be noted that the suggestions of the judges in Delphi I for the items that needed to be revised were regarding their form of presentation and reallocation. In the bundle, requests were made to change the title of the bundle, adding complications after handling, given the importance of including adverse situations that may affect cancer patients. In "concerning management" conducts, the time for changing the fully implanted central venous catheter dressing (FICVC) was made, i.e., changing it every seven days, in the case of a transparent film, and replace dressings if dirt, moisture or loosened. Also included, the friction of the catheter hub with antiseptics (alcoholic chlorhexidine $0.5 \%$ or alcohol $70 \%$ ).

Another request was withdrawn from the collection of two blood culture samples, if the temperature is higher than $38.0^{\circ} \mathrm{C}$ or if patients received CT in the last 14 days; however, this item was not fulfilled, since FN represents a serious complication with high mortality. In "pediatric-specific" actions, the first item on CVC burrows was condensed into one of the "regarding management" items, due to not being specific to the pediatric population.

In the Delphi II round, it was feasible to reach an agreement index for all analyzed items related to the bundle content, in which credibility and accuracy were the most satisfactorily assessed (CVC $=0.95$ and CVC $=0.94$, respectively). Regarding the general estimate, the instrument had CVC $=0.93$ at this stage.

It is noteworthy that in Delphi I and II, none of the items had a CVC below $80.0 \%$, all the items analyzed were statistically significant $(\rho \leq 0.05)$ regarding agreement among experts.

Concerning pilot test, nurses with practical experience in the oncology outpatient clinic of CT (mean $=4.16$ and standard deviation $=3.24$ ), mean age of 32.16 and standard deviation of 5.90, whose average training time was 5.12 and standard deviation of 4.36 participated. These nurses considered that the bundle met the objectives for which it was proposed and recommended its use/application in sectors that assist cancer patients. They only suggested word reduction without losing meaning in some items. The instrument had CVC $=1.0$ in this phase.

\section{DISCUSSION}

The construction and assessment of a bundle content for the prevention and management of complications of neutropenia in cancer patients was developed with methodological rigor in order to allow scientific knowledge to be accessible to nursing professionals working in oncology. 
Table 2 - Agreement among judges in Delphi I and II stages for the assessed items of bundle content for the prevention and management of complications in neutropenia in cancer patients, Minas Gerais, Brazil, 2020, ( $n=16$ e $n=14)$

\begin{tabular}{|c|c|c|c|c|c|c|c|c|c|c|}
\hline \multirow{3}{*}{ Items } & \multicolumn{10}{|c|}{ Complication Prevention and Management Actions/Measures } \\
\hline & \multicolumn{2}{|c|}{$\begin{array}{l}\text { Concerning } \\
\text { risk factors }\end{array}$} & \multicolumn{2}{|c|}{$\begin{array}{l}\text { Concerning } \\
\text { prevention }\end{array}$} & \multicolumn{2}{|c|}{$\begin{array}{c}\text { Concerning } \\
\text { management }\end{array}$} & \multicolumn{2}{|c|}{$\begin{array}{c}\text { Concerning specific } \\
\text { management for pediatrics }\end{array}$} & \multicolumn{2}{|c|}{$\begin{array}{l}\text { Concerning } \\
\text { nursing team }\end{array}$} \\
\hline & $\begin{array}{l}\text { Delphi I } \\
\text { ( } \rho \text { value*) }\end{array}$ & $\begin{array}{l}\text { Delphi II } \\
\text { ( } \rho \text { value*) }\end{array}$ & $\begin{array}{l}\text { Delphi I } \\
\text { ( } \rho \text { value*) }\end{array}$ & $\begin{array}{l}\text { Delphi II } \\
\text { ( } \rho \text { value*) }\end{array}$ & $\begin{array}{l}\text { Delphi I } \\
\text { ( } \rho \text { value*) }\end{array}$ & $\begin{array}{l}\text { Delphi II } \\
\text { ( } \rho \text { value*) }\end{array}$ & $\begin{array}{c}\text { Delphi I } \\
\text { ( } \rho \text { value*) }\end{array}$ & $\begin{array}{l}\text { Delphi II } \\
\text { ( } \rho \text { value*) }\end{array}$ & $\begin{array}{l}\text { Delphi I } \\
\text { ( } \rho \text { value*) }\end{array}$ & $\begin{array}{l}\text { Delphi II } \\
\text { ( } \rho \text { value*) }\end{array}$ \\
\hline Behavior & $\begin{array}{l}85.41 \% \\
(0.003)^{* *}\end{array}$ & $\begin{array}{l}87.5 \% \\
(0.03)^{* *}\end{array}$ & $\begin{array}{l}87.5 \% \\
(0.03)^{* *}\end{array}$ & $\begin{array}{l}87.5 \% \\
(0.03)^{* *}\end{array}$ & $\begin{array}{l}85.41 \% \\
(0.003)^{* *}\end{array}$ & $\begin{array}{l}83.3 \% \\
(0.03)^{* *}\end{array}$ & $\begin{array}{l}93.7 \% \\
(0.03)^{* *}\end{array}$ & $\begin{array}{l}100 \% \\
(0.00)\end{array}$ & $\begin{array}{l}91.6 \% \\
(0.03)^{* *}\end{array}$ & $\begin{array}{l}100 \% \\
(0.00)\end{array}$ \\
\hline Objectivity & $\begin{array}{l}85.41 \% \\
(0.003)^{* *}\end{array}$ & $\begin{array}{l}87.5 \% \\
(0.03)^{* *}\end{array}$ & $\begin{array}{c}91.6 \% \\
(0.03)^{* *}\end{array}$ & $\begin{array}{l}85.41 \% \\
(0.003)^{* *}\end{array}$ & $\begin{array}{l}85.41 \% \\
(0.003)^{* *}\end{array}$ & $\begin{array}{l}83.3 \% \\
(0.03)^{* *}\end{array}$ & $\begin{array}{c}93.7 \% \\
(0.03)^{* *}\end{array}$ & $\begin{array}{c}97.7 \% \\
(0.03)^{* *}\end{array}$ & $\begin{array}{l}93.7 \% \\
(0.03)^{* *}\end{array}$ & $\begin{array}{l}100 \% \\
(0.00)\end{array}$ \\
\hline Simplicity & $\begin{array}{l}81.25 \% \\
(0.002)^{* *}\end{array}$ & $\begin{array}{l}85.41 \% \\
(0.03)^{* *}\end{array}$ & $\begin{array}{l}87.5 \% \\
(0.03)^{* *}\end{array}$ & $\begin{array}{l}83.3 \% \\
(0.03)^{* *}\end{array}$ & $\begin{array}{l}85.41 \% \\
(0.003)^{* *}\end{array}$ & $\begin{array}{l}85.41 \% \\
(0.03)^{* *}\end{array}$ & $\begin{array}{l}95.8 \% \\
(0.03)^{* *}\end{array}$ & $\begin{array}{l}100 \% \\
(0.00)\end{array}$ & $\begin{array}{c}91.6 \% \\
(0.03)^{* *}\end{array}$ & $\begin{array}{l}100 \% \\
(0.00)\end{array}$ \\
\hline Clarity & $\begin{array}{l}87.5 \% \\
(0.03)^{* *}\end{array}$ & $\begin{array}{l}85.41 \% \\
(0.03)^{*}\end{array}$ & $\begin{array}{c}87.5 \% \\
(0.03)^{* *}\end{array}$ & $\begin{array}{c}87.5 \% \\
(0.03)^{* *}\end{array}$ & $\begin{array}{c}83.3 \% \\
(0.03)^{* *}\end{array}$ & $\begin{array}{l}85.41 \% \\
(0.03)^{* *}\end{array}$ & $\begin{array}{c}93.7 \% \\
(0.03)^{* *}\end{array}$ & $\begin{array}{l}100 \% \\
(0.00)\end{array}$ & $\begin{array}{c}95.8 \% \\
(0.03)^{* *}\end{array}$ & $\begin{array}{l}100 \% \\
(0.00)\end{array}$ \\
\hline Relevance/pertinence & $\begin{array}{c}97.9 \% \\
(0.03)^{* *}\end{array}$ & $\begin{array}{l}85.41 \% \\
(0.03)^{* *}\end{array}$ & $\begin{array}{c}97.9 \% \\
(0.03)^{* *}\end{array}$ & $\begin{array}{c}87.5 \% \\
(0.03)^{* *}\end{array}$ & $\begin{array}{c}91.6 \% \\
(0.03)^{* *}\end{array}$ & $\begin{array}{c}87.5 \% \\
(0.03)^{* *}\end{array}$ & $\begin{array}{c}93.7 \% \\
(0.03)^{* *}\end{array}$ & $\begin{array}{l}100 \% \\
(0.00)\end{array}$ & $\begin{array}{c}97.7 \% \\
(0.03)^{* *}\end{array}$ & $\begin{array}{l}100 \% \\
(0.00)\end{array}$ \\
\hline Precision & $\begin{array}{c}91.6 \% \\
(0.03)^{* *}\end{array}$ & $\begin{array}{c}87.5 \% \\
(0.03)^{* *}\end{array}$ & $\begin{array}{c}97.3 \% \\
(0.03)^{* *}\end{array}$ & $\begin{array}{c}85.41 \% \\
(0.003)^{* *}\end{array}$ & $\begin{array}{c}89.5 \% \\
(0.03)^{* *}\end{array}$ & $\begin{array}{c}97.7 \% \\
(0.03)^{* *}\end{array}$ & $\begin{array}{c}89.5 \% \\
(0.03)^{* *}\end{array}$ & $\begin{array}{l}100 \% \\
(0.00)\end{array}$ & $\begin{array}{c}95.8 \% \\
(0.03)^{* *}\end{array}$ & $\begin{array}{l}100 \% \\
(0.00)\end{array}$ \\
\hline Variety & $\begin{array}{c}95.8 \% \\
(0.03)^{* *}\end{array}$ & $\begin{array}{c}83.3 \% \\
(0.02)^{* *}\end{array}$ & $\begin{array}{c}89.5 \% \\
(0.03)^{* *}\end{array}$ & $\begin{array}{c}85.41 \% \\
(0.003)^{* *}\end{array}$ & $\begin{array}{c}83.3 \% \\
(0.02)^{* *}\end{array}$ & $\begin{array}{c}97.7 \% \\
(0.03)^{* *}\end{array}$ & $\begin{array}{c}97.7 \% \\
(0.03)^{* *}\end{array}$ & $\begin{array}{c}97.7 \% \\
(0.03)^{* *}\end{array}$ & $\begin{array}{c}91.6 \% \\
(0.03)^{* *}\end{array}$ & $\begin{array}{l}100 \% \\
(0.00)\end{array}$ \\
\hline Modality & $\begin{array}{c}91.6 \% \\
(0.03)^{* *}\end{array}$ & $\begin{array}{l}85.41 \% \\
(0.03)^{* *}\end{array}$ & $\begin{array}{c}89.5 \% \\
(0.03)^{* *}\end{array}$ & $\begin{array}{c}85.41 \% \\
(0.003)^{* * *}\end{array}$ & $\begin{array}{c}89.5 \% \\
(0.03)^{* *}\end{array}$ & $\begin{array}{c}97.7 \% \\
(0.03)^{* *}\end{array}$ & $\begin{array}{c}97.7 \% \\
(0.03)^{* *}\end{array}$ & $\begin{array}{l}100 \% \\
(0.00)\end{array}$ & $\begin{array}{c}93.7 \% \\
(0.03)^{* *}\end{array}$ & $\begin{array}{l}100 \% \\
(0.00)\end{array}$ \\
\hline Typicality & $\begin{array}{c}91.6 \% \\
(0.03)^{* *}\end{array}$ & $\begin{array}{c}87.5 \% \\
(0.03)^{* *}\end{array}$ & $\begin{array}{l}85.41 \% \\
(0.03)^{*}\end{array}$ & $\begin{array}{c}83.3 \% \\
(0.03)^{* *}\end{array}$ & $\begin{array}{c}83.3 \% \\
(0.02)^{* *}\end{array}$ & $\begin{array}{c}97.7 \% \\
(0.03)^{* *}\end{array}$ & $\begin{array}{c}97.7 \% \\
(0.03)^{* *}\end{array}$ & $\begin{array}{l}100 \% \\
(0.00)\end{array}$ & $\begin{array}{c}93.7 \% \\
(0.03)^{* *}\end{array}$ & $\begin{array}{l}100 \% \\
(0.00)\end{array}$ \\
\hline Credibility & $\begin{array}{c}93.7 \% \\
(0.03)^{* *}\end{array}$ & $\begin{array}{c}87.5 \% \\
(0.03)^{* *}\end{array}$ & $\begin{array}{c}93.7 \% \\
(0.03)^{* *}\end{array}$ & $\begin{array}{r}85.41 \% \\
(0.003)^{* * *}\end{array}$ & $\begin{array}{c}95.8 \% \\
(0.03)^{* *}\end{array}$ & $\begin{array}{l}100 \% \\
(0.00)\end{array}$ & $\begin{array}{c}89.5 \% \\
(0.03)^{* *}\end{array}$ & $\begin{array}{l}100 \% \\
(0.00)\end{array}$ & $\begin{array}{c}95.8 \% \\
(0.03)^{* *}\end{array}$ & $\begin{array}{l}100 \% \\
(0.00)\end{array}$ \\
\hline Breadth & $\begin{array}{c}93.7 \% \\
(0.03)^{* *}\end{array}$ & $\begin{array}{c}87.5 \% \\
(0.03)^{* *}\end{array}$ & $\begin{array}{c}97.3 \% \\
(0.03)^{* *}\end{array}$ & $\begin{array}{c}85.41 \% \\
(0.003)^{* *}\end{array}$ & $\begin{array}{c}89.5 \% \\
(0.03)^{* *}\end{array}$ & $\begin{array}{l}100 \% \\
(0.00)\end{array}$ & $\begin{array}{c}93.7 \% \\
(0.03)^{* *}\end{array}$ & $\begin{array}{l}100 \% \\
(0.00)\end{array}$ & $\begin{array}{c}95.8 \% \\
(0.03)^{* *}\end{array}$ & $\begin{array}{c}95.3 \% \\
(0.03)^{* *}\end{array}$ \\
\hline Balance & $\begin{array}{c}95.8 \% \\
(0.03)^{* *}\end{array}$ & $\begin{array}{c}87.5 \% \\
(0.03)^{* *}\end{array}$ & $\begin{array}{c}93.7 \% \\
(0.03)^{* *}\end{array}$ & $\begin{array}{c}83.3 \% \\
(0.03)^{* *}\end{array}$ & $\begin{array}{c}93.7 \% \\
(0.03)^{* *}\end{array}$ & $\begin{array}{c}97.7 \% \\
(0.03)^{* *}\end{array}$ & $\begin{array}{c}93.7 \% \\
(0.03)^{* * *}\end{array}$ & $\begin{array}{l}100 \% \\
(0.00)\end{array}$ & $\begin{array}{c}93.7 \% \\
(0.03)^{* *}\end{array}$ & $\begin{array}{l}93.7 \% \\
(0.03)^{*}\end{array}$ \\
\hline
\end{tabular}

Note: ${ }^{*}$ Binomial test; ${ }^{* *} \rho \leq 0.05$.

Patients who are undergoing $\mathrm{CT}$ are likely to develop FN. About $10 \%$ to $20 \%$ of these are likely to be affected by adverse situations that can lead to death, if not diagnosed and treated early ${ }^{(5,7)}$.

High-risk neutropenic patients, according to the MASCC severity index ${ }^{(5)}$, need to receive broad-spectrum intravenous antibiotic therapy (ATB), with an indication for hospitalization. Individuals with low risk and intermediate risk of complications can be considered candidates for oral or intravenous ATB, most of the time, without the need for hospitalization ${ }^{(5)}$.Thus, delays in detecting the risk of neutropenia can lead to severe damage to the person's health and, in their assessment, nurses must identify the risk factors for FN as early as possible, in addition to the design and implementation of preventive actions and management of complications $s^{(3,47)}$.

A bundle assists in the process, as it is an instrument that guides professionals in their conduct, since it has appropriate formal quality, easy to read, content based on scientific evidence ${ }^{(8,48)}$.

During the bundle research and construction, the following stood out: the effectiveness of education on self-care; Telenursing use; periodic nursing consultation; hand hygiene before any access to CVC; preferably use a closed infusion system; implement assistance protocols linked to permanent education, in addition to the guidance of patients and family members; assess the risk factors for infection; be prepared to recognize the indicators of sepsis, severe sepsis, and septic shock; monitor the use of G-CSF and/or antibiotics to reduce $\mathrm{FN}$ in patients who received $\mathrm{QT}$, according to organizational protocol ${ }^{(5-7,18)}$.

Many studies have shown that nurses, who work in the oncology field, play a fundamental role in the design, development and development of a formal risk assessment tool with international guidelines related to $\mathrm{FN}$, while working together with the entire multidisciplinary team ${ }^{(6-7,18)}$.

To the initial format of the bundle, no items were added to those initially listed. This implies that specialists considered the verification items related to the conduct regarding risk factors, prevention, management, specific management for pediatrics and the nursing team to prevent and manage complications of neutropenia in cancer patients sufficient. The recommendations allowed the achievement of the desired objective, in addition to the increase in the instrument's agreement and reliability.

It should be noted that of the 37 items of the instrument, the changes made consisted of clarity and typicality (in the item "regarding management") and precision (in the item "regarding specific management of pediatrics"). In the second module it was only necessary to spell check the entire bundle.

Regarding the level of scientific evidence for bundle items, most publications were derived from well-designed cohort and case-control studies (level IV - 38.8\%) and at least one single descriptive or qualitative study (level $\mathrm{VI}-22.2 \%$ ).

This may suggest that FN management is based on cohort, case-control and descriptive studies; however, the lack of clinical trials can be clarified by the entanglement in guaranteeing reliability and legitimacy, by the diversity of variables and, mainly, by the ethical judgments that make the existence of a control group unenforceable ${ }^{(49)}$.

The assessment process involved the participation of 16 judges in Delphi I ( $1^{\text {st }}$ round) and 14 of these judges in Delphi II ( $2^{\text {nd }}$ round). 
Reliability and validity are essential criteria for assessing the quality of an instrument. In this perspective, validity is related to the fact that an instrument measures exactly what it is suggested to measure. Reliability is the ability to stress a result properly. They are essential criteria for the quality of an instrument ${ }^{(11)}$.

In this study, we highlight the significant experience of the judges participating in assessment stages, who were $\mathrm{PhD}$ with high experience in teaching and practicing in oncology, both in care and management. Literature shows that master's degree and $\mathrm{PhD}$ degree holders are largely responsible for enabling repercussions in practices and, therefore, in the advancement of nursing ${ }^{(15)}$.

In this logic, authors point out in a previous study that Brazilian nurses with some type of stricto sensu graduate education (specialization) fit into a reality that is guided by policies that materialize and cause innovations in their acts to achieve significant educational, scientific and technological impacts for nursing and health ${ }^{(50)}$.

Therefore, it is understood that the participation of experienced judges and involved in assistance, management and research is relevant for the assessment of instruments to be applied in practice, as this study proposed when assessing a bundle for prevention and management complications of neutropenia in cancer patients.

Concerning the Delphi technique used to consult a group of expert judges on the topic, the objective was not to deduce a simple answer or just reach agreement, but quality opinions and responses were obtained for a given investigation presented to a panel of experts, as recommended by the methodological framework ${ }^{(11)}$.

After the bundle assessment, the judges presented a significant coefficient of agreement in all the items assessed, in order to make the instrument valid in relation to behavior, objectivity, simplicity, clarity, relevance, precision, variety, modality, typicality, credibility, breadth, and balance ${ }^{(11,51)}$.

Judges' suggestions regarding FN management were to remove two blood culture samples, if patients' temperature is above $38.0^{\circ} \mathrm{C}$ and he received $\mathrm{CT}$ in the last 14 days; however, this item did not was fulfilled, since $\mathrm{FN}$ is s a serious complication with mortality that can reach levels above $50 \%(5,7,18)$.

The measurement of axillary temperature greater than $38.0^{\circ} \mathrm{C}$, being a single episode or several, is already an alert for a picture of FN. Laboratory tests are carried out in the presence of fever, including blood culture, and if the neutrophil count is less than $500 \mathrm{~mm}^{3}$ in the next 48 hours, FN diagnosis is confirmed ${ }^{(7)}$.

Other items suggested in these conducts were the adequacy of the time for changing the fully implanted CVC dressing and including rubbing the catheter hub with antiseptics $(0.5 \%$ alcoholic chlorhexidine or $70 \%$ alcohol). Literature points out that if a patient is sweating or if the site of insertion of the CVC is bleeding, a gauze dressing should be used until this is resolved, and replace the dressing at the catheter site whenever it becomes damp, loose or visibly dirty. If transparent dressings are used, replace every seven days ${ }^{(52)}$.
Disinfection on surfaces of needle-free connectors and intravascular access devices (catheter hub) needs to be carried out before any manipulation, using appropriate antiseptic agent in mechanical friction, whose recommended solutions are $0.5 \%$ alcoholic chlorhexidine or $70 \%$ alcohol, in order to decrease the number of microorganisms on its surface. Such measures involve training, use of a sterile barrier and establishment of care routines for handling $\mathrm{CVC}^{(53)}$.

Literature points out that the acceptable coefficient of agreement among the members of the expert committee must be at least 0.80 and, preferably, greater than $0.90^{(51)}$, as shown in this study $(C V C=0.93)$. Such variations proved to be statistically significant $(\rho \leq 0.05)$, which demonstrates the achievement of the best agreement associated with improvements in the instrument between Delphi rounds, in addition to the instrument being shown to be reliably applicable in practice.

Finally, a pilot test carried out in an UNACON, in order to verify its adequacy and efficiency. It was well assessed by all participating nurses. They only suggested word reduction without losing meaning in some items, and the beginning of follow-up implementation via Telenursing was considered a success with great return both for the professional and for patients followed up in the initial period of 30 days.

\section{Study limitations}

One of the limitations of this study is related to not conducting a more robust research than a pilot test, another point to be highlighted is the definition of judges, which is not always easy to achieve. In this study, we chose to use the criteria proposed by Fehring ${ }^{(13)}$, which considers aspects based on clinical experience, but it cannot be guaranteed, in fact, that all items become a guarantee of clinical expertise.

\section{Contributions to nursing and health}

The study's contribution to nursing and health is the possibility of bundle subsidizing the health care of people with malignant neoplasia, directing the use of good health practices in order to prevent and manage the complications of neutropenia in cancer patients, being an essential context for NP.

\section{CONCLUSIONS}

The results obtained in the study of bundle construction and assessment for the prevention and management of complications of neutropenia in cancer patients pointed out psychometric properties permissible for its use in oncology health services. Agreement among judges provided evidence for bundle reliability, with changes to the items they advised. The instrument assessment was measured with a significant outcome, following the methodological rigor of the Delphi technique. After pilot test, the participating nurses recommended using bundle in sectors that care for cancer patients.

\section{REFERENCES}

1. Bernabeu-Martínez MA, Ramos-Merino M, Santos-Gago JM, Álvarez-Sabucedo LM, Wanden-Berghe C, Sanz-Valero J. Guidelines for safe handling of hazardous drugs: a systematic review. PLoS One. 2018;13(5):e0197172. https://doi.org/10.1371/journal.pone.0197172 
2. Oliveira PP. Challenges of quality and patient safety in oncology services. Revista de Enfermagem do Centro-Oeste Mineiro. 2017; 7:eEditorial. https://doi.org/10.19175/recom.v7i0.2692

3. Na Z, Qiaoyuan Y, Binghan W, Qin Z, Yue C, Xin P, et al. A developed model of cancer patient participation in intravenous chemotherapy safety. Oncotarget. 2017;8(50):87598-606. https://doi.org/10.18632/oncotarget.20986

4. Riul S, Aguillar OM. Quimioterapia antineoplásica: revisão da literatura. Rev Min Enf [Internet]. 1999 [cited 2019 Dec 5];3(1/2):60-7. Available from: https://cdn.publisher.gn1.link/reme.org.br/pdf/v3n1a11.pdf

5. Ferreira JN, Correia LRBR, Oliveira RM, Watanabe SN, Possari JF, Lima AFC. Managing febrile neutropenia in adult cancer patients: an integrative review of the literature. Rev Bras Enferm. 2017;70(6):1301-8. https://doi.org/10.1590/0034-7167-2016-0247

6. Tarakcioglu CGH, Korkmaz F. Nurses' knowledge and care practices for infection prevention in neutropenic patients. Contemp Nurse. 2017;53(2):143-55. https://doi.org/10.1080/10376178.2016.1254566

7. Ying FLM, Ping MCY, Tong M, Yan EYP, Yee TLS, Ting LY, et al. A cohort study on protocol-based nurse-led out-patient management of postchemotherapy low-risk febrile neutropenia. Support Care Cancer. 2018;26(9):3039-45. https://doi.org/10.1007/s00520-018-4157-6

8. Melo JMA, Oliveira PP, Rodrigues AB, Souza RS, Fonseca DF, Gontijo TF, et al. Bundle construction and assessment before antineoplastic extravasation: a methodological study. Acta Paul Enferm. 2020;33:eAPE20190075. https://doi.org/https://doi.org/10.37689/acta-ape/2020ao0075

9. Silva AG, Oliveira AC. Impact of the bundles implementation on the reduction of bloodstream infections: an integrative review. Texto Contexto Enferm. 2018;27(1):e3540016. https://doi.org/10.1590/0104-07072018003540016

10. Conselho Federal de Enfermagem. Resolução COFEN 569/2018. Aprova o Regulamento Técnico da Atuação dos Profissionais de Enfermagem em Quimioterapia Antineoplásica. Brasília (DF). [Internet]. 2018. [cited 2019 Dec 30]. Available from: http://www.cofen.gov.br/ resolucao-cofen-no-0569-2018_60766.html

11. Pasquali L. Instrumentação psicológica: fundamentos e práticas. Porto Alegre: Artmed; 2010.

12. Medeiros SG. Avaliação da segurança no uso de vacinas na Atenção Primária à Saúde [Tese]. Natal: Universidade Federal do Rio Grande do Norte; 2019

13. Fehring RJ. The Fehring Model. In: M. Paquete R. Carrol-Johnson. Classification of nursing diagnoses: proceedings of the tenth conference of North American Nursing Diagnosis Association. Philadelphia: Lippincott; 1994.

14. Aguiar LL, Guedes MVC, Galindo NNM, Melo GAA, Almeida PC, Oliveira RM, et al. Validation of a safety assessment instrument for chronic renal patients on hemodialysis. Acta Paul Enferm. 2018;31(6):609-15. https://doi.org/10.1590/1982-0194201800084

15. Gomes AT, Alves KY, Bezerril MS, Rodrigues CC, Ferreira Jr MA, Santos VE. Validation of graphic protocols to evaluate the safety of polytrauma patients. Acta Paul Enferm. 2018;31(5):504-17. https://doi.org/10.1590/1982-0194201800071

16. Oliveira PP, Rodrigues AB, Gimenez JA, Santos MK, Silveira EAA. A humanização da assistência na ótica de profissionais de enfermagem que cuidam de idosos. Investig Enferm Imagen Desarr. 2018;20(2):1-12. https://doi.org/https://doi.org/10.11144/Javeriana.ie20-2.haop

17. Rodrigues $A B$, Cunha GH, Aquino CBQ, Rocha SR, Mendes CRS, Firmeza MA, et al. Head and neck cancer: validation of a data collection instrument. Rev Bras Enferm. 2018;71(4):1899-906. https://doi.org/10.1590/0034-7167-2017-0227

18. Oliveira PP, Freitas ATS, Maia PA, Amaral RAC, Fonseca DF, Franco ECD. Cuidados de enfermagem para pacientes oncológicos neutropênicos: scoping review. Rev N Min Enferm. [Internet]. 2019 [cited 2021 Jan 5]; 8(2):17-28. Available from: https://www.periodicos.unimontes.br/ index.php/renome/article/view/2255/2333

19. Tricco AC, Lillie E, Zarin W, O'Brien KK, Colquhoun H, Levac D, et al. PRISMA Extension for Scoping Reviews (PRISMA-ScR): checklist and Explanation. Ann Intern Med. 2018;169(7):467-73. https://doi.org/10.7326/M18-0850

20. Peters MDJ, Godfrey C, Mclnerney P, Baldini SC, Khalil H, Parker D. Chapter 11: scoping reviews. In: Aromataris E, Munn Z (Editors). Joanna Briggs Institute Reviewer's Manual. The Joanna Briggs Institute [Internet]. 2017 [cited 2019 Jul 05]. Available from: https://reviewersmanual. joannabriggs.org/

21. Best JT, Frith K, Anderson F, Rapp CG, Rioux L, Ciccarello C. Implementation of an evidence-based order set to impact initial antibiotic time intervals in adult febrile neutropenia. Oncol Nurs Forum. 2011;38(6):661-8. https://doi.org/10.1188/11.0NF.661-668

22. Chang LL, Schneider SM, Chiang SC, Horng CF. Implementing an evidence-based risk assessment tool to predict chemotherapy-induced neutropenia in women with breast cancer. Cancer Nurs. 2013;36(3):198-205. https://doi.org/10.1097/NCC.0b013e3182642d98

23. Conley SB. Central Line-Associated Bloodstream Infection Prevention: Standardizing Practice Focused on Evidence-Based Guidelines. Clin J Oncol Nurs. 2016;20(1):23-6. https://doi.org/10.1188/16.CJON.23-26

24. Considine J, Livingston P, Bucknall T, Botti M. A review of the role of emergency nurses in management of chemotherapy-related complications. J Clin Nurs. 2009;18(18):2649-55. https://doi.org/10.1111/j.1365-2702.2009.02843.x

25. DeMille $D$, Deming $P$, Lupinacci $P$, Jacobs $L A$. The effect of the neutropenic diet in the outpatient setting: a pilot study. Oncol Nurs Forum. 2006;33(2):337-43. https://doi.org/10.1188/ONF.06.337-343

26. Donohue R. Development and implementation of a risk assessment tool for chemotherapy-induced neutropenia. Oncol Nurs Forum. 2006;33(2):347-52. https://doi.org/10.1188/06.ONF.347-352

27. Duffy EA, Rodgers CC, Shever LL, Hockenberry MJ. Implementing a daily maintenance care bundle to prevent central line-associated bloodstream infections in pediatric oncology patients. J Pediatr Oncol Nurs.2015;32(6):394-400. https://doi.org/10.1177/1043454214563756 
Bundle for the prevention and management of complications of neutropenia in cancer patients Amaral RAC, Oliveira PP, Fonseca DF, Schlosser TCM, Moraes JT, Silveira EAA, et al.

28. Flores IQ, Ershler W. Managing neutropenia in older patients with cancer receiving chemotherapy in a community setting. Clin J Oncol Nurs. 2010;14(1):81-6. https://doi.org/10.1188/10.CJON.81-86

29. Griffiths P, Richardson A, Blackwell R. Outcomes sensitive to nursing service quality in ambulatory cancer chemotherapy: systematic scoping review. Eur J Oncol Nurs. 2012;16(3):238-46. https://doi.org/10.1016/j.ejon.2011.06.004

30. Hawley EL, Loney M, Wiece M. Development of tools and processes to improve treatment times in patients with febrile neutropenia. Clin J Oncol Nurs. 2011;15(5):e53-e57. https://doi.org/10.1188/11.CJON.E53-E57

31. Kearney N, Friese C. Clinical practice guidelines for the use of colony-stimulating factors in cancer treatment: Implications for oncology nurses. Eur J Oncol Nurs. 2008;12(1):14-25. https://doi.org/10.1016/j.ejon.2007.10.001

32. Leonard K. A European survey relating to cancer therapy and neutropenic infections: nurse and patient viewpoints. Eur J Oncol Nurs. 2012;16(4):380-6. https://doi.org/10.1016/j.ejon.2011.08.004

33. Mattison G, Bilney M, Haji-Michael P, Cooksley T. A nurse-led protocol improves the time to first dose intravenous antibiotics in septic patients post chemotherapy. Support Care Cancer. 2016;24(12):5001-05. https://doi.org/10.1007/s00520-016-3362-4

34. Miller K. Using a computer-based risk assessment tool to identify risk for chemotherapy-induced febrile neutropenia. Clin J Oncol Nurs. 2010;14(1):87-91. https://doi.org/10.1188/10.CJON.87-91

35. Montoya L. Managing hematologic toxicities in the oncology patient. J Infus Nurs. 2007;30(3):168-72. https://doi.org/10.1097/01 . NAN.0000270676.59180.c3

36. Moore K, Crom D. Hematopoietic support with moderately myelosuppressive chemotherapy regimens: a nursing perspective. Clin J Oncol Nurs. 2006;10(3):383-8. https://doi.org/10.1188/06.CJON.383-388

37. Moore K, Fortner B. Utility of routine nurse assessment of the risk of chemotherapy-induced febrile neutropenia. Can Oncol Nurs J. 2010;20(2):75-9. https://doi.org/10.5737/1181912×2027579

38. Nirenberg A, Mulhearn L, Lin S, Larson E. Emergency department waiting times for patients with cancer with febrile neutropenia: a pilot study. Oncol Nurs Forum. 2004 13;31(4):711-5. https://doi.org/10.1188/04.ONF.711-715

39. Nirenberg A, Reame NK, Cato KD, Larson EL. Oncology nurses' use of National Comprehensive Cancer Network clinical practice guidelines for chemotherapy-induced and febrile neutropenia. Oncol Nurs Forum. 2010;37(6):765-73. https://doi.org/10.1188/10.0NF.765-773

40. O'Brien C, Dempsey O, Kennedy MJ. Febrile neutropenia risk assessment tool: improving clinical outcomes for oncology patients. Eur J Oncol Nurs. 2014;18(2):167-74. https://doi.org/10.1016/j.ejon.2013.11.002

41. Olsen JP, Baldwin S, Houts AC. The Patient Care Monitor-Neutropenia Index: development, reliability, and validity of a measure for chemotherapy-induced neutropenia. Oncol Nurs Forum. 2011;38(3):360-7. https://doi.org/10.1188/11.0NF.360-367

42. Shelton BK, Stanik-Hutt J, Kane J, Jones RJ. Implementing the surviving sepsis campaign in an ambulatory clinic for patients with hematologic malignancies. Clin J Oncol Nurs. 2016;20(3):281-8. https://doi.org/10.1188/16.CJON.281-288

43. Smith LH, Besser SG. Dietary restrictions for patients with neutropenia: a survey of institutional practices. Oncol Nurs Forum [Internet]. 2000 [cited 2019 Mar 10];27(3):515-20. Available from: https://pubmed.ncbi.nlm.nih.gov/10785904/

44. White N, Maxwell C, Michelson J, Bedell C. Protocols for managing chemotherapy-induced neutropenia in clinical oncology practices. Cancer Nurs. 2005;28(1):62-9. https://doi.org/10.1097/00002820-200501000-00009

45. Zhou Y, Cui Y, Wang H, Wang F, Lu C, Shen Y. Developing a tool for nurses to assess risk of infection in pediatric oncology patients in China: a modified Delphi study. J Biomed Res. 2016;30(5):386-92. https://doi.org/10.7555/JBR.30.20160014

46. Melnyk BM, Fineout-Overholt E. Evidence-based practice in nursing \& healthcare: a guide to best practice. 2a ed. Philadelphia: Lippincot Williams \& Wilkins; 2011.

47. Weingart SN, Zhang L, Sweeney M, Hassett M. Drug safety in oncology 1: chemotherapy medication errors. Lancet Oncol. 2018;19:e191-99. https://doi.org/10.1016/S1470-2045(18)30094-9

48. Freund Y, Khoury A, Möckel M, Karamercan M, Dodt C, Leach R, et al. European Society of Emergency Medicine position paper on the 1-hour sepsis bundle of the Surviving Sepsis Campaign: expression of concern. Eur J Emerg Med. 2019; 26(4):232-33. https://doi.org/1097/ MEJ.0000000000000603

49. Borgert M, Binnekade J, Paulus F, Goossens A, Dongelmans D. A flowchart for building evidence-based care bundles in intensive care: based on a systematic review. Int J Qual Health Care. 2017; 29(2):163-75. https://doi.org/10.1093/intqhc/mzx009

50. Scochi CGS, Munari DB, Gelbcke FL, Erdmann AL, Gutiérrez MGR, Rodrigues RAP. The strict sense nursing postgraduation in Brazil: advances and perspectives. Rev Bras Enferm. 2013;66(Spe):80-9. https://doi.org/10.1590/S0034-71672013000700011

51. Souza AC, Alexandre NMC, Guirardello EB. Psychometric properties in instruments evaluation of reliability and validity. Epidemiol Serv Saúde. 2017;26(3):649-59. https://doi.org/10.5123/S1679-49742017000300022

52. Fonseca DF, Oliveira PP, Amaral RAC, Nicoli LHS, Silveira EAA, Rodrigues AB. Care protocol with totaly implanted venous catheter: a collective construction. Texto Contexto Enferm. 2019;28:e20180352. https://doi.org/10.1590/1980-265x-tce-2018-0352

53. Yu XY, Xu JL, Li D, Jiang ZF. Late complications of totally implantable venous access ports in patients with cancer: risk factors and related nursing strategies. Medicine (Baltimore). 2018;97(38):e12427. https://doi.org/10.1097/MD.0000000000012427 